\title{
Cattle's Physiology and Behavior Responses Which Transported by Camara Nusantara Vessel
}

\author{
Shabrina Dyah Wibawanti*, Mohammad Yamin, Rudi Afnan and Rudy Priyanto \\ Department of Animal Products Technology, Faculty of Animal Science, IPB University, Bogor, West Java, Indonesia \\ *Corresponding author email: shabrinashaby@ymail.com
}

Abstract. This study aimed to assess the welfare and performance of Bali cattle transported by Camara Nusantara vessel. We observed five-day transporting of 30 Bali cattle (1-2 years old, 100-200kg body weight) from cattle loading at Tenau Port, Kupang and cattle handling during sea transportation to cattle unloading at Tanjung Priok Port, Jakarta. The measured parameters were cattle's physiological responses, including body surface temperature, foaming (excessive foam around their mouth), respiration (respiration rate during transportation), and panting (any panting behavior during the transport). The behavioral responses measured in this study were feeding behavior (do cattle eat normally during transportation process), lying (can cattle lie normally), agonistic interaction (mounting, head fighting, etc.), freeze during the loading/ unloading process (stop walking during loading and unloading process), coercion (cattle was hit during loading and unloading process), and slip/fall (cattle slipped or fell during loading and unloading process). The welfare evaluation was carried out by scoring system on the observed parameters. The result showed that the cattle showed a normal physiological response, except their body surface temperature was slightly above normal, i.e., $32-35^{\circ} \mathrm{C}$. The cattle also showed normal behavior responses except for coercion. The average score gets from this study was 2.5 , indicative of slightly poor physiology and behavior when cattle being transported.

Keywords: cattle's phisiology, behaviour, cattle transportation, camara nusantara vessel

\begin{abstract}
Abstrak. Penelitian ini bertujuan untuk mengkaji kesejahteraan dan performa sapi yang ditransportasikan menggunakan KM Camara Nusantara. Penelitian dilakukan mulai dari proses loading, di Pelabuhan Tenau, hingga unloading di Pelabuhan Tanjung Priuk, Jakarta selama 5 hari. Pengamatan meliputi proses loading/ unloading dan proses pelayaran berlangsung. Peubah yang diukur antara lain respon fisiologis (suhu permukaan tubuh, respirasi foaming, dan panting) dan respon tingkah laku (makan, berbaring, interaksi agonistik, terdiam saat proses loading/ unloading, koersi, dan terpeleset/terjatuh. Parameter kesejahteraan ternak selama proses transportasi diukur dengan sistem skoring pada peubah yang diamati. Secara umum, respon fisiologis bernilai baik, kecuali pada suhu permukaan tubuh berada di atas normal yaitu $32-35^{\circ} \mathrm{C}$. Respon tingkah laku menunjukkan normal, kecuali pada parameter coercion. Hasil rata-rata skor pengukuran selama proses transportasi menunjukkan angka 2,5. Angka ini menunjukkan bahwa aspek fisiologi ternak dan perilaku ternak selama proses transportasi sedikit buruk.
\end{abstract}

Kata kunci: fisiogi ternak, perilaku ternak, trnasportasi ternak, KM Camara Nusantara

\section{Introduction}

Logistics is part of the supply chain process where implementation and control of the flow and storage of goods, services, and related information from the point of origin to the consumer take place to fulfill more effective and efficient handling of orders and requests, including demand for beef. Indonesia has 17,058 islands where its population increases annually. BSN estimated that the growth rate of the Indonesian population in 2010-2016 increased by $1.36 \%$. While the Indonesian population is concentrated in Java Island, the cattle production centers are mostly located in the middle and eastern part of Indonesia, including South Sulawesi, West Nusa Tenggara, East Nusa Tenggara, and Lampung, as the home for $67 \%$ of the total cattle population in Indonesia.

Cattle welfare is a crucial concept and a reference in the livestock sector from upstream to downstream which, according to Broom (2001), is part of cattle business sustainability. The term livestock welfare applies to the physical and psychological 
health of cattle, including their ability to behave naturally, physical comfort, and absence of diseases and hunger (Welfare Quality ${ }^{\circledR}$ 2009). The aspect of livestock welfare is now the highlight of the world, especially during transport. Unfortunately, livestock transport handling in Indonesia that follows the rules of animal welfare that encompass transporting to ships, during the trip, and arrival still has many shortcomings.

It encourages the Government to make a breakthrough in the livestock transport system, especially between islands using KM Camara Nusantara ships. Until today, interisland cattle shipping uses goods vessels that are not specialized for cattle transportation, so its function, design, and handling are far from considering the welfare aspect of the livestock.

The sea toll is a government initiative to streamline Indonesia's logistics lines and an alternative to address the issue of livestock welfare aspects in cattle distribution. The Government also developed a specified livestock vessel called "KM Camara Nusantara 1 " that made its maiden voyage in December 2015, transporting cattle from Nusa Tenggara islands to Java Island. In addition to the KM Camara Nusantara 1, five other Governmentprovided vessels were launched in early 2018.

The vessel is designed to qualify the rules of livestock welfare, minimize weight loss and poor performance. To the best of our knowledge, there has been limited investigation on cattle welfare standards applied in the transportation, the information process, and the study of the transportation process of KM Camara Nusantara on livestock performance and welfare aspect. Therefore, in our study of sea transportation using KM Camara Nusantara on the welfare and performance of cattle, we expect to evaluate the effect of sea transportation using the Camara Nusantara ship on cattle's physiology and behavior response.

\section{Materials and Methods}

\section{Time and location Research}

The research was conducted in KM Camara Nusantara 3 Camara Nusantara 3 which carried cattle from Kupang to Tanjung Priok in December 2018.

\section{Livestock}

We observed a total of 30 Bali cattle from 3 decks, from which 10 cattle were chosen.

\section{Research materials}

The tools used in this research were assessment form, stationery, and camera.

\section{Parameters}

Parameters measured in this research were physiology responses and behaviour responses as follows:

1. Physiology responses:

a. Panting were observed during transportation process and assessed using a four-scale scoring system, 1 being the worst and 4 the best.

b. Respiration rate was observed by looking at the contraction of the rib at 7 am, $12 \mathrm{am}$, and $4 \mathrm{pm}$.

c. Body surface temperature was measured using an infrared thermometer directed to four points of the cattle body (forehead, hips/rump, back, and lower abdomen/rear flank).

d. Foaming were observed using a fourscale scoring system, 1 being the worst and 4 the best.

2. Behaviour response were observed using a four-scale scoring system from 1 (worst score) to 4 (best score) for the following activities:
a. Eating
b. Laying
c. Agonistic interaction
d. Coercion
e. Freezing during loading/unloading
f. Slip/ fall

\section{Procedure}

From 250 Bali cattle transported with KM Camara Nusantara, we selected 30 male Bali 
cattle (10 from each deck A, B and C) for observation based on the ownership. The observations were undertaken in different decks and pens every day for 15 minutes at 7 am, $12 \mathrm{pm}$, and $4 \mathrm{pm}$. The parameters are measured qualitatively using asessment form.

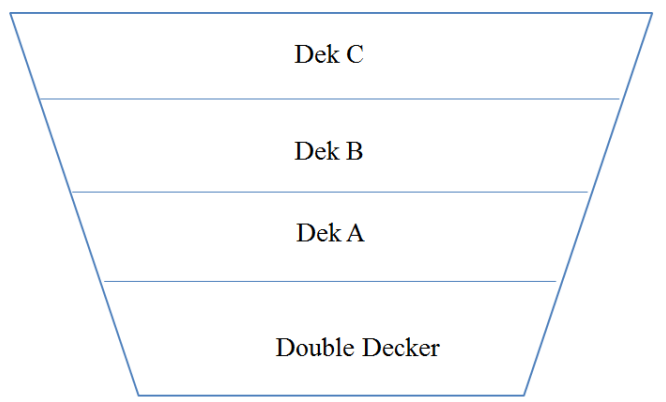

Figure 1. Deck's map on the ship

\section{Data analysis}

This study performed qualitative and quantitative data analysis. Descriptivequalitative analysis processed and presented data in tables, graphs, and research documentation to describe the empirical reality of one aspect in livestock logistics activities.
Quantitative data analysis (total feed consumption, weight loss, environmental temperature and humidity, mortality, and physiology) of the livestock on decks $A, B$, and $C$ were analyzed in a Completely Randomized Design. P1: Cattle on deck A; P2: Cattle on deck B; P3: Cattle on deck C.

Respiration and body surface temperatur were analyzed with the repeated analysis measurement. Coercion, freeze during loading/unloading process, slipped/ fell, bruises/wounds, and lameness were analyzed with the paired t-test to compare between loading and unloading process.

Data were processed with SPSS and the scoring value was subjected to descriptive statistics analysis using Microsoft Excel program.

Data scoring was performed using the rubric table. The criteria of each parameter were based on the corresponding literature (Table 1). The scoring was categorized from 14, 1 being the worst and 4 the best. The final results were obtained from combining and averaging these scoring values.

Table 1. criteria and scoring each parameter and variable

\begin{tabular}{|c|c|c|c|c|c|}
\hline \multirow{2}{*}{ Parameters } & \multirow{2}{*}{ Variable } & \multicolumn{4}{|c|}{ Criteria and Scoring } \\
\hline & & 1 & 2 & 3 & 4 \\
\hline \multirow[t]{4}{*}{$\begin{array}{l}\text { Physiology } \\
\text { Responses }\end{array}$} & $\begin{array}{l}\text { Foaming } \\
\text { (ASEL, 2011) }\end{array}$ & $\begin{array}{l}\text { There was a } \\
\text { constant amount } \\
\text { of foam from the } \\
\text { mouth of cattle }\end{array}$ & $\begin{array}{l}\text { There was } \\
\text { a little } \\
\text { foam on } \\
\text { the mouth }\end{array}$ & $\begin{array}{l}\text { Mouth opened, } \\
\text { but no foam }\end{array}$ & $\begin{array}{l}\text { No foam from } \\
\text { the cattle } \\
\text { mouth }\end{array}$ \\
\hline & $\begin{array}{l}\text { Panting } \\
\text { (ASEL, 2011) }\end{array}$ & $\begin{array}{l}\text { The mouth } \\
\text { opened, obvious } \\
\text { panting, the } \\
\text { tongue stuck out } \\
\text { and excessive } \\
\text { drooling or } \\
\text { foaming }\end{array}$ & $\begin{array}{l}\text { Panting, } \\
\text { only a } \\
\text { little } \\
\text { amount of } \\
\text { drooling or } \\
\text { foaming }\end{array}$ & $\begin{array}{l}\text { A little bit } \\
\text { panting, the } \\
\text { mounth was } \\
\text { closed, no } \\
\text { drooling or } \\
\text { foaming, ribs } \\
\text { contraction could } \\
\text { be seen }\end{array}$ & $\begin{array}{l}\text { No panting, } \\
\text { difficult to see } \\
\text { ribs } \\
\text { contraction }\end{array}$ \\
\hline & $\begin{array}{l}\text { Respiration } \\
\text { (Eley, 2011) }\end{array}$ & $\begin{array}{l}\geq 40 \text { times }^{-} \\
\text {minutes }^{-1}\end{array}$ & $\begin{array}{l}30-40 \\
\text { times } \\
\text { minutes }^{-1}\end{array}$ & $\begin{array}{l}20-30 \text { times }^{-1} \\
\text { minutes }^{-1}\end{array}$ & $\begin{array}{l}1-20 \text { times }^{-} \\
\text {minutes }^{-1}\end{array}$ \\
\hline & $\begin{array}{l}\text { Body Surface } \\
\text { temperature } \\
\text { (Lysyk, 2008) }\end{array}$ & $\geq 35^{\circ} \mathrm{C}$ & $34-34.99^{\circ} \mathrm{C}$ & $33-34^{\circ} \mathrm{C}$ & $32-33^{\circ} \mathrm{C}$ \\
\hline
\end{tabular}


Shabrina Dyah Wibawanti et al./Animal Production. 23(3): 187-196, 2021

Accredited by Kemenristek Dikti No 32a/E/KPT/2017. ISSN 1411-2027

\begin{tabular}{|c|c|c|c|c|c|}
\hline \multirow{2}{*}{ Parameters } & \multirow{2}{*}{ Variable } & \multicolumn{4}{|c|}{ Criteria and Scoring } \\
\hline & & 1 & 2 & 3 & 4 \\
\hline \multirow[t]{6}{*}{$\begin{array}{l}\text { Behaviour } \\
\text { Response }\end{array}$} & $\begin{array}{l}\text { Eating } \\
\text { (ASEL, 2011) }\end{array}$ & $\begin{array}{l}\text { Only } \leq 25 \% \text { of } \\
\text { the total } \\
\text { population were } \\
\text { eating }\end{array}$ & $25-50 \%$ & $50-75 \%$ & $75-100 \%$ \\
\hline & $\begin{array}{l}\text { Agonistic } \\
\text { interaction } \\
\text { (ASEL, 2011) }\end{array}$ & $\begin{array}{l}75-100 \% \text { of the } \\
\text { cattle showed } \\
\text { agonistic } \\
\text { interaction }\end{array}$ & $50-75 \%$ & $25-50 \%$ & $25 \%$ \\
\hline & $\begin{array}{l}\text { Lying down } \\
\text { (ASEL, 2011) }\end{array}$ & $\begin{array}{l}\leq 25 \% \text { of the } \\
\text { cattle were lying } \\
\text { down }\end{array}$ & $25-50 \%$ & $50-75 \%$ & $75-100 \%$ \\
\hline & $\begin{array}{l}\text { Freeze during } \\
\text { loading/ } \\
\text { unloading } \\
\text { (ASEL, 2011) }\end{array}$ & $\begin{array}{l}\text { Cattle freezed } \\
\text { more than } 5 \\
\text { seconds }\end{array}$ & $\begin{array}{l}3-5 \\
\text { seconds }\end{array}$ & 1-2 seconds & No freezing \\
\hline & $\begin{array}{l}\text { Coercion } \\
\text { (European } \\
\text { Comission, } \\
\text { 2017) } \\
\end{array}$ & $\begin{array}{l}\text { Cattle was hit } \geq 5 \\
\text { times }\end{array}$ & 3-4 times & $1-2$ times & No hitting \\
\hline & $\begin{array}{l}\text { Slipped/ fell } \\
\text { (ASEL, 2011) }\end{array}$ & $\begin{array}{l}\text { Cattle slipped/ } \\
\text { fell more than } 5 \\
\text { times }\end{array}$ & 4-5 times & $1-3$ times & $\begin{array}{l}\text { No slipping/ } \\
\text { falling }\end{array}$ \\
\hline
\end{tabular}

\section{Results and Discussion}

KM Camara Nusantara is a livestock vessel used to transport cattle from East Nusa Tenggara to Java Island. This vessel is included in the government's sea toll program to improve the distribution of livestock logistics and to provide solutions for shipping cattle from eastern Indonesia to Java Island. To the best of our knowledge, no studies have investigated the transportation of cattle with KM of Camara Nusantara I, especially on the aspect of livestock welfare.

According to Haryana and Nuryati (2016), the livestock transportation mechanism of using the KM livestock ship Camara Nusantara is more effective than the conventional transportation system in terms of costs, time of delivery, livestock weight loss at the destination, total cost, and efficiency chains.

\section{Physiology Response}

The physiological response is one indicator of prolonged stress in cattle. The physiological responses measured in this study include foaming, panting, respiration, and the cattle body's surface temperature. The physiological response observed was presented in Table 2 .

Table 1 shows the panting cattle score during the journey ranged between 3.9 and 4, indicative of only a few cattle were panting during the transportation. The score showe significant differences across decks $(P<0.05)$ in which, unlike cattle on the $\operatorname{deck} A$ and $B$, cattle on the deck $C$ did not show any sign of panting during transportation process.

During the transportation, cattle did not show any sign of foaming, which may indicate heat stress. Despite the dangerous level of the temperature-humidity index in Camara Nusantara 3, the manifestation of panting and foaming was not present. If the cattle did not show panting as a heat stress manifestation, they had a higher respiration rate. According to Ohnstand (2016), the manifestation of heating up can be demonstrated with a higher panting or respiration rate. 
Table 2. Scoring of Foaming and panting during transportation process

\begin{tabular}{lccc}
\hline Parameters & Deck A & Deck B & Deck C \\
\hline Foaming (skor) & $4 \pm 0.00$ & $4 \pm 0.00$ & $4 \pm 0.00$ \\
Panting (skor) & $3.94 \pm 0.29^{\mathrm{b}}$ & $4.0 \pm 0.0^{\mathrm{a}}$ & $3.92 \pm 0.3^{\mathrm{b}}$ \\
\hline
\end{tabular}

Table 3. Body surface temperature and respiration each deck

\begin{tabular}{|c|c|c|c|c|}
\hline \multirow{2}{*}{ Observation Time } & \multicolumn{3}{|c|}{ Deck Location } & \multirow{2}{*}{ Average } \\
\hline & Dek A & Dek B & Dek C & \\
\hline \multicolumn{5}{|c|}{ Body surface temperature } \\
\hline $09.00 \mathrm{am}$ & $34.21 \pm 0.99$ & $32.65 \pm 0.99$ & $34.14 \pm 0.99$ & $33.67 \pm 0.99^{c}$ \\
\hline $12.00 \mathrm{am}$ & $35.25 \pm 4.37$ & $33.18 \pm 0.81$ & $34.72 \pm 1.01$ & $34.38 \pm 1.0^{\mathrm{a}}$ \\
\hline $04.00 \mathrm{pm}$ & $32.62 \pm 5.19$ & $32.96 \pm 0.93$ & $34.72 \pm 1.01$ & $33.87 \pm 1.1^{\mathrm{b}}$ \\
\hline Average & $34.67 \pm 1.1^{a}$ & $32.93 \pm 0.91^{c}$ & $34.32 \pm 1.0^{b}$ & $33.97 \pm 1.03$ \\
\hline \multicolumn{5}{|l|}{ Respiration } \\
\hline $09.00 \mathrm{am}$ & $23.52 \pm 3.59$ & $16.56 \pm 1.96$ & $18.04 \pm 2.71$ & $19.37 \pm 2.7^{b}$ \\
\hline $12.00 \mathrm{am}$ & $25.48 \pm 3.37$ & $19.76 \pm 3.3$ & $22.36 \pm 4.66$ & $22.53 \pm 3.7^{\mathrm{a}}$ \\
\hline $04.00 \mathrm{pm}$ & $21.64 \pm 4.35$ & $17.06 \pm 2.19$ & $20.86 \pm 3.54$ & $19.85 \pm 3.3^{b}$ \\
\hline Average & $23.55 \pm 3.77$ & $17.79 \pm 2.48$ & $20.42 \pm 3.63$ & $20.58 \pm 3.23$ \\
\hline
\end{tabular}

\section{Respiration}

Cattle respiration can be observed from the beef ribs and varies according to the ambient temperature. The average respiration of cattle transported in KM Camara Nusantara ship showed significant results $(P<0.05)$ on each deck (Table 3).

Table 3 shows cattle on deck $A$ had the highest respiration value of all decks due to the higher THI score on deck A (84.03) but remained within the normal limit. This finding confirms Eley (2011) that cattle respiration ranges from 10-30 per minute and rises to 2650 times under stress conditions.

\section{Body Surface Temperature}

The body surface temperature is one factor in the physiological state. The surface temperature value of the cattle's body transported by Camara Nusantara 3 showed a significant difference $(P<0.05)$ of each deck. Body surface temperature score was further tested with a repeated measurement analysis. The average surface temperature in our study (Table 3) ranged between 32.93 and $34.670 \mathrm{C}$, in which the highest was in $\operatorname{deck} A$ and the lowest in deck $B$. This result corresponds with
Windi (2010) that cattle's skin surface responds to temperature changes because the skin is the outer layer protection of the livestock from the environment that plays a crucial role in maintaining body temperature.

The respiration rate of cattle transported in Camara Nusantara 3 ship is worth 2, based on Lysyk (2008).

\section{Behaviour Response}

Cattle behaviour is one of the indicators to cattle welfare. The parameters assessed included eating behavior, agonistic interactions, and lying behaviour (Table 4).

\section{Eating}

Livestock eating and drinking behaviors assessed whether cattle actually ate and drank at the time of observation. The observation results showed that the percentage of livestock that actually ate and drank was $13 \%$ $14 \%$ due to low feed intake that accounted for 0.9-2 kg head ${ }^{-1}$ day $^{-1}$, which is below daily consumption minimum. The few numbers of livestock in this behaviour category may be due to the unpalatable feed in the ship that differ from the farm. 
Table 4. Cattle behaviour

\begin{tabular}{lccc}
\hline Parameters & Deck A & Deck B & Deck C \\
\hline $\begin{array}{l}\text { Eating behaviour } \\
\text { Yes (\%) }\end{array}$ & 13 & 14 & 13 \\
$\quad$ No (\%) & 87 & 86 & 87 \\
$\begin{array}{l}\text { Agonistic Interaction } \\
\text { Yes (\%) }\end{array}$ & & & \\
$\quad$ No (\%) & 11.72 & 9.16 & 14.78 \\
Laying Behaviour & 88.28 & 90.84 & 85.22 \\
$\quad$ Yes (\%) & & & \\
No (\%) & 60.46 & 60.82 & 64.88 \\
\hline
\end{tabular}

According to the Ministry for Primary Industries of New Zealand (2013), feed adaptation crucial to prevent the livestock from shock of sudden change in the types of feed. Only few livestock that perform feed activities potentially results in high weight loss number.The best score is given when all cattle consume the feed. The total cattle eating on KM Camara Nusantara was $13-14 \%$, so that the scoring for eating behaviour is 2 .

\section{Agonistic Interactions}

The agonistic interactions observed during transportation included pushing heads or horns, butting, and mounting each other. Agonistic interactions occurred during the transport process are presented in Table 4.

Table 4 shows the agonistic interactions of cattle transported with KM Camara Nusantara vessels ranged between $9.16 \%$ and $14.78 \%$. mostly pushing each other's heads. The low number of agonistic interactions during transportation may attributed to the condition where Bali cattle were tied to the fence during the transportation. The agonistic interaction could have increased if the cattle had been untied during the transportation.

Agonistic interactions can occur due to the mixing of cattle that do not belong in one herd and begin to compete for the higher hirarchy. Such agonistic interactions may cause bruising in the Warris Cattle (1990).

The scoring value for the agonistic behavior of good livestock is if the whole livestock performs agonistic activities. The value of agonistic cattle behavior on Camara Nusantara vessels ranges from $9-14 \%$, so the scoring value obtained is 2 .

\section{Lying}

Lying down is one of the parameters of livestock comfort during transport. A lay judgment is done with the observer and assessed through the scoring system. The results of cattle behavior during the transportation process are presented in Table 2. The number of cattle that lay down was only $60-64 \%$ because the pen capacity was over the limit, so the distance between cattle was too close, around $0.75-1.3 \mathrm{~m}$ (Figure 3 ). The standard distance of cattle tied during the transportation process is not yet established. 
In our observation, we estimated that the proper distance between cattle was 1 meter.

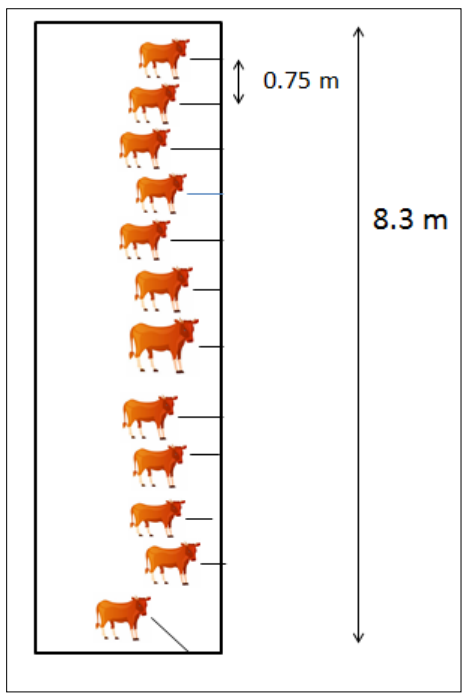

Figure 3. Overview cattle spacing inside the pen

According to Gallo et al. (2000), in the long transportation process, adult cattle tend to lie down after 12 hours of transportation. Grandin (2007) stated that in long-distance transport, $20 \%$ of adult cattle would lie down while the vehicle was moving. Grandin (2007) added that the cattle that could not lie down due to the high stocking density transportation process might suffer from fatigue and finally lay down towards the end of the transportation process. Cattle that suffer from fatigue will take a longer recovery time in the feedlot, thus a disadvantage for the feedloter.

The number of coercion, bruising or wounds, freezing during the loading/unloading process, and slip/fall are cattle behavior response indicators during the loading/unloading process. The assessment results are presented in Table 5.

\section{Slip or fall}

Fall or slip will put the cattle at risk of injury or bruising. The scoring value of the slip/drop parameter in Table 5 shows that the scoring on the indicator slipped or dropped on the loading and unloading process is $2.01 \pm 1.08$ and $2 \pm 1.14$, which means the cattle slipped 3 4 times in the loading or unloading process. The comparison between the loading and unloading process showed insignificant results $(P>0.05)$, indicating no significant differences in cattle handling during the loading and unloading process.

The criteria of proper cattle handling include the absence of cattle fall or slip during the unloading process. Cattle fell or slipped due to the slippery vessel floor or when taking a sharp U-turn. According to Grandin (2014), a gangway should be made with a curved shape, not a sharp bend. The cattle will resist a sharp turn and will panic when forced, thus easy to fall and slip and even scare the other cattle.

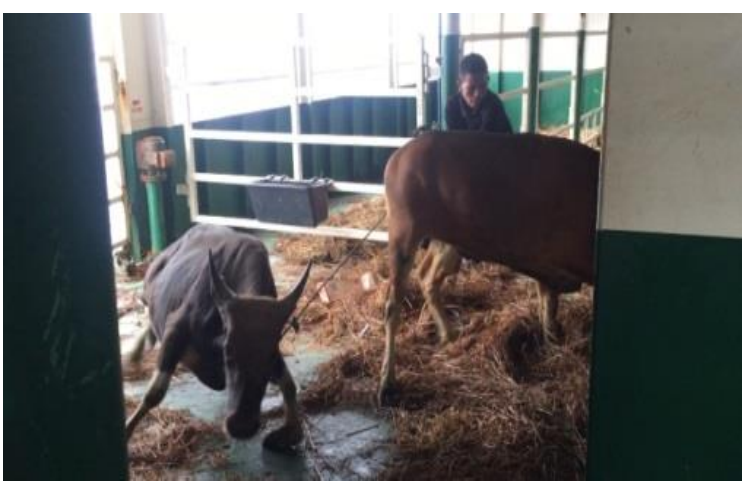

Figure 4. Cattle slipped during loading

Since a slippery surface may cause livestock to slip in the loading and unloading process in KM Camara Nusantara, the staff mitigated this risk by spreading hay on the floor surface.

Table 5. Cattle behaviour scoring during loading and unloading

\begin{tabular}{lcc}
\hline Parameter & Loading & Unloading \\
\hline Slip or fall & $2.01 \pm 1.08$ & $2 \pm 1.14$ \\
Coercion & $1.20 \pm 0.51$ & $1.05 \pm 0.28$ \\
Freeze & $2.76 \pm 1.14$ & $2.68 \pm 1.22$ \\
\hline
\end{tabular}


It confirms the Commonwealth Australia Standard 3 Division 2 (2015) that the floor in gangways or ramps must have a non-slippery surface which, according to The Australian Animal Health Council (2016), can reduce the risk of remoting, falling, and slipping on cattle.

\section{Coercion}

Coercion is defined as the use of objects, e.g., electric sticks, sticks, whips to hit, kick, whip, give shock using an electric goad, or bend the tail of the animal. The scoring assessment is calculated from the types of coercion to live cattle, which in this study ranged from $1.2 \pm 0.51$ for loading and 1.05 \pm 0.28 for the unloading (Table 5 ). The figure shows the cattle were inclined to move more than five times. The comparison between the loading and unloading process showed insignificant results $(P>0.05)$. It indicated no significant differences in cattle handling during the loading and unloading process.

The cattle that have been hit can be at risk of bruising. Bruising in cattle may incur losses due to the compromised quality of the meat produced. The statement is in line with Jones (1994), which stated that the coercion on cattle will cause stress on livestock and produce a lower quality of meat.

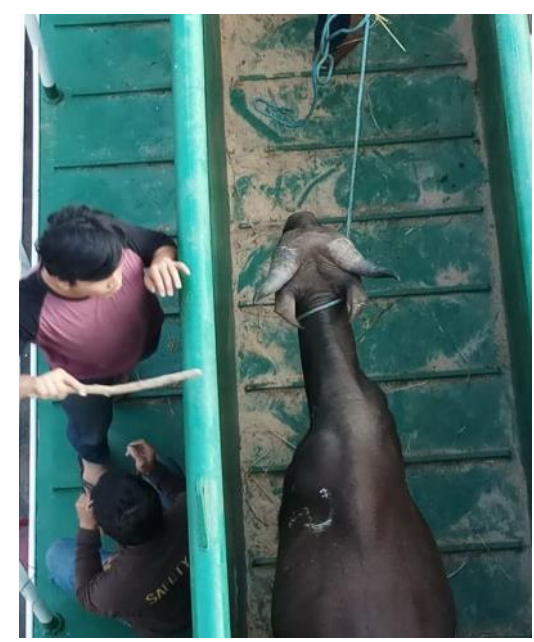

Figure 5. Coercion during unloading process

The cattle that have been hit can be at risk of bruising. Bruising in cattle may incur losses as they can decrease the quality of the meat produced. The statement is in line with Jones (1994) that coercion on cattle will cause stress and eventually result in a lower quality of meat.

\section{Freeze during Loading/Unloading}

Freeze when loading or unloading means being immobile during the process of loading or unloading. Cattle that do not move in the loading or unloading process may be afraid of the environmental changes or many people passing by. The mean score of cattle freeze during the loading or unloading process in Table 5 is two, which means the cattle did not move for 3-4 seconds in the process of loading or unloading. The cattle froze or became immobile due to either the number of people who were passing in the gangway or the condition of trucks that were not ready during the unloading process. As a result, the loading or unloading durations are delayed.

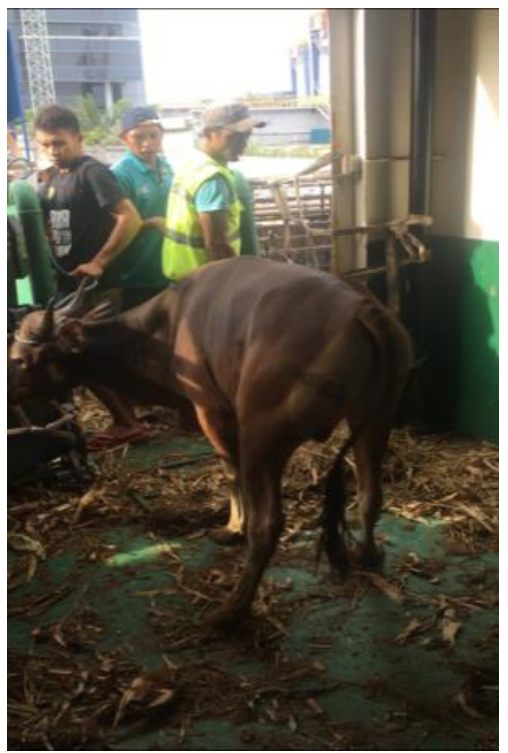

Figure 6. Unloading condition in Tanjung Priuk

The Commonwealth Australia (2011) advised the loading or unloading process be undertaken by a few officers. Too many officers potentially make the cattle afraid and risk them of stress. Before the cattle descended, both truck officers must be 
prepared at the port to avoid the long wait for the truck preparation.

Another factor that caused cattle to freeze during the loading/unloading process is probably improper handling management. Cattle will move if the position of the officer is behind the balance point (European Comission, 2017). We observed that Bali cattle were tied by rope, so they have to be pulled one by one during the loading/unloading process. Consequently, the cattle froze because there was an officer in front of them that blocked their view.

\section{Final score calculation}

The final score is determined by totaling the number of scores of each aspect and then taking average The final score of the cattle behavior and physiology response is presented in table 6.

Table 6. Final score of cattle physiology and behaviour response

\begin{tabular}{|c|c|c|c|c|}
\hline \multirow{2}{*}{ Parameters } & \multicolumn{4}{|c|}{ Score } \\
\hline & 1 & 2 & 3 & 4 \\
\hline \multicolumn{5}{|l|}{ Physiology response } \\
\hline Panting & & & & 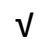 \\
\hline Respiration rate & & & $\mathrm{v}$ & \\
\hline Body surface temperature & & & $\checkmark$ & \\
\hline Foaming & & $\checkmark$ & & \\
\hline \multicolumn{5}{|l|}{ Behaviour response } \\
\hline Eating & $\sqrt{ }$ & & & \\
\hline Laying & & & & $\mathrm{v}$ \\
\hline Agonistic interaction & & & $\checkmark$ & \\
\hline Coercion & & $\sqrt{ }$ & & \\
\hline Freezing during loading/unloading & $\mathrm{v}$ & & & \\
\hline Slip/fall & & $\mathrm{v}$ & & \\
\hline
\end{tabular}

The total score of physiology and behavior response was 25 with an average score of 2.5 of 4 , indicative of poor physiology and behavior responses among cattle transported with Camara Nusantara. In brief, Camara Nusantara has a poor implementation of animal welfare.

\section{Conclusions}

Cattle's physiology and behavior during transportation using KM Nusantara Vessel were slightly poor, indicating slightly stressed cattle. Further study with more parameters is needed to improve the welfare of cattle transportation in Indonesia.

\section{Acknowledgement}

This research was supported by NICHE (Netherland Initiative For Capacity Development In Higher Education), PT. Pelni
Indonesia, and all the ship's crew of Camara Nusantara 3.

\section{References}

Animal Health Australia. 2016. Australian Animal Welfare Standards and Guidelines for cattle. 1st Ed. www.animalwelfarestandards.net.au. (Accessed 29 March 2019).

Australian Standard for Export of Livestock. 2011. Australian position statement on the export of livestock. Department of Agriculture, Fisheries, and Forestry, Canberra, Australia. 132 pages

Broom, D.M. 2010. Effects of dairy cattle breeding and production methods on animal welfare. Proc. 21st World Buiatrics Congress, 1-7. Punta del Este, Uruguay: World Association for Buiatics

Eley, T. 2011. The health Cow. https://www.nadis.org.uk/disease-a-z/cattle/thehealthy-cow/ (accesed 29 January 2019)

Gallo, C, S Perez, C Sanhueza, and J Gasic. 2000. Efectos del tiempo de transporte de novillos previo al faenamiento sobre el comportamiento, las perdidas de peso y algunas caracteristicas de 
la canal. Archivos de Medicina Veterinaria. 32: 157-170.

Ganong. 1983. Review of Medical Physiology. Ed ke11. California: Lange Medical Publication.

Grandin, T. 2007. Livestock Handling and Transportat. 3rd Ed., CABI Publishing, Oxfordshire

Grandin, T. 2014. Livestock Handling and Transport: Theories and Applications. 4th ed. CABI Publ., Wallingford, UK.

Jones, RB, DG Satterlee, and FH Ryder. 1994. Fear of humans in Japanese quail selected for low or high adrenocortical response. Physiol. Behav. 56, 379-383.

Lysyk, TJ. 2008. Effects of Ambient Temperature and Cattle Skin Temperature on Engorgement of Dermacentor andersoni. J. Med. Entomol. 45(6): 1000-1006

Ministry for Primary Insdustries of New Zealand. 2013. Guidance Material for the Transport of
Cattle by Sea. https://www.mpi.govt.nz/ exporting/animals/live-animals/requirementdocuments-for-exporting-live-animals/animalwelfare-export-certificates/live-sheep-and-cattleexport-voyage-reports/. (Accessed 29 March 2019)

Ohnstand, I. 2016. Managing heat stress in Dairy Cow. https://www.nadis.org.uk/disease-az/cattle/managing-heat-stress-in-dairy-cows/ (accesed 29 January 2019)

Dahl, PK, L Foldager, MS Herskin, H Houe, and PT Thompsen. 2018. Lameness scoring and assessment of fitness for transport in dairy cows. Res Vet Sci.;119:162-166

Warris, PD. 1990. The Handling of Cattle preslaughter and its effect on carcass and meat quality. Applied Anim Behaviour Sci, 28: 171-186

Welfare Quality $^{\circledR}$. 2009. Welfare Quality ${ }^{\circledR}$ assessment protocol for cattle. Welfare Quality ${ }^{\circledR}$ Consortium, Lelystad, Netherlands. 